\title{
Международное
}

гуманитарное право

\section{СЕРЬЕЗНЫЕ НАРУШЕНИЯ МЕЖДУНАРОДНОГО ГУМАНИТАРНОГО ПРАВА И ИМПЛЕМЕНТАЦИЯ БОРЬБЫ С НИМИ В УГОЛОВНОМ ЗАКОНОДАТЕЛЬСТВЕ РЕСПУБЛИКИ БЕЛАРУСЬ}

В.Ю. К ал уги н*

В настоящее время в международных отношениях продолжают сушествовать источники войн и вооруженных конфликтов. Войны и вооруженные конфликты порождают определенные правоотношения как между воюющими сторонами, так и между не участвуюшими в конфликте сторонами. Значение международно-правового регулирования данных отношений посредством правил ведения войны постоянно возрастает. Это объясняется стремлением если не исключить войну из сферы международного общения, то снизить трагические последствия вооруженных конфликтов путем формулирования правил, ограничивающих воюющих в выборе средств и способов ведения военных действий, обеспечивающих защиту лиц, не принимаюших непосредственного участия или прекративших принимать участие в боевых действиях (гражданское население, раненые, больные, военнопленные и т.п.).

Кроме того, очень сушественным моральным фактором для стороны, ведушей боевые действия, являются поддержка населением своей страны и позитивное отношение со стороны мирового сообшества. Такое отношение возможно только при соблюдении международно-правовых законов и обычаев войны, которые в концентрированном виде содержатся в такой отрасли международного публичного права, ках международное гуманитарное право. К его главным договорам присоединилось большинство государств мира.

Однако присоединение к договорам является лишь первым шагом. Требуются усилия для претворения норм международного гуманитарного права в жизнь, для применения их на практике. И здесь главная ответственность за обеспечение эффективной реализачии международного гуманитар-

* Секретарь Комиссии по имплементации международного гуманитарного права при Совете министров Республики Беларусь. 
ного права ложится на государства, которые.должны принимать соответствуюшие меры, в первую очередь на национальном уровне. Одной из таких мер является пресечение нарушений международного гуманитарного права, включая ввод в действие национального законодательства, необходимого для предотврашения таких нарушений и при необходимости для обеспечения наказания за совершение преступлений, связанных с нарушением законов и обычаев войны.

Республика Беларусь как участница абсолютного большинства международных договоров по защите жертв войны (например, для Беларуси четыре Женевские конвенции от 12 августа 1949 г. вступили в силу с 3 февраля 1955 г., а Дополнительные протоколы х Женевским конвенциям от 8 июня 1977 г. - с 23 апреля 1990 г.) обязана обеспечить реализацию принятых на себя международных обязательств, в том числе н в области пресечения нарушений международного гуманитарного права путем трансформации этих положений в национальное законодательство.

Со второй половины XIX века в доктрине международного права считается общепризнанным, что существуют такие преступные действия или преступное бездействне, связанные с нарушением законов и обычаев ведения войны, за совершение которых международное право возлагает на виновных лиц уголовную ответственность. Эти воззрения начали складываться на основе подходов, которые первоначально формулировались во внутригосударственном законодательстве. Например, в Ннструкции полевым войскам США от 24 апреля 1863 г., подготовленной известным юристом Фрэнсисом Либером, говорилось о том, что солдаты, виновные в совершении нарушений права войны, должны подвергаться судебному преследованию независимо от того, принадлежат они $\mathrm{k}$ вооруженным силам США или являются пленными противника.

Первые попытки создания мехдународной системы ответственности за нарушение права войны были предприняты после окончания первой мировой войны. 11 ноября 1918 г. была сформирована Союзническая комиссия для установления ответственности “военных преступников” (данный термин был использован впервые). В Версальском мирном договоре предлагалось привлечь к ответственности кайзера Вильгельма II и других обвиняемых в военных преступлениях граждан Германии, а также создать международный суд и национальные суды для процессов над военными преступниками всех видов. Ухазанные предложения не были воплощены в жизнь: кайзер в это время спасался бегством в Голландия, которая отказалась его выдать, а те немногие из предполагаемых военных преступников, которые подверглись судебному преследованию, были или оправданы, или получили чисто символическое наказание ${ }^{1}$.

Реальное воплощение этих воззрений в нормы международного права об уголовной ответственности отдельных лиц за нарушение права войны произошло в ходе и после второй мировой войны. Уже в нотах НКИД СССР от 25 ноября 1941 г., 6 января и 27 апреля 1942 г. Советское правительство потребовало «суровой ответственности и наказания преступного фашистского правительства Германии за его разбойные действия"2. Положения об утоловной ответственности отдельньх лиц были сформулированы и закреплены в решениях Московской (1943 г.), Крымской (1945 г.) и Потсдамской 
(1945 г.) конференций. Так, в решениях Московской конференции министров иностранных дел СССР, США и Англии говорилось, что германские офицеры, солдаты и члены гитлеровской партии, которые имеют какоелибо отношенне $\mathrm{K}$ зверствам, убийствам и казням в странах, захваченных германскими вооруженными силами, “будут доставлены обратно в страны, где совершены их ужасные преступления, для того, чтобы они подверглись обвинению и наказанию по законам этих стран"3. В решениях Крымской конференции от 11 февраля 1945 г. ее участники взяли на себя обязательства "подвергнуть всех преступнихов войны справедливому и быстрому наказанию"4; в решениях Потсдамской конференции закреплялось обязательство государств арестовывать и предавать суду военных преступников и тех "кто участвовал в планировании или осуществлении нацистских мероприятий, влекущих за собой или имеющих своим результатом зверства или военные преступления"s.

Конкретно нормы об уголовной ответственности отдельных физических лиц были сформулированы в уставах и приговорах Международных военных трибуналов для суда над главными немецкими и японскими военными преступниками. Так, ст. 6 Устава Международного военного трибунала, прилагаемого к Соглашению между правительствами Союза Советских Социалистических Республик, Соединенных Штатов Америки, Соединенного Королевства Великобритании и Северной Ирландии и Временным правительством Французской Республики о судебном преследовании и наказании главных военных преступников европейских стран "оси" от 8 августа 1945 г. устанавливала:

"Следующие действия, или любые из них, являются преступлениями, подлежащими юрисдикции Трибунала и влекущими за собой индивидуальную ответственность:

a) Преступления против мира, а именно: планирование, подготовка, развязывание или ведение агрессивной войны или войны в нарушение международных договоров, соглашений или заверений, или участие в общем плане или заговоре, направленных $\mathrm{x}$ осушествлению любого из вышеизложенных действий;

b) Военные преступления, а именно: нарушение захонов или обычаев войны. $\mathrm{K}$ этим нарушениям относятся убийства, истязания или увод в рабство или для других целей гражданского населения оккупированной территории; убийства и истязания военнопленных или лиц, находящихся в море; убийства заложников; ограбление общественной или частной собственности; бессмысленное разрушение городов или деревень; разорение, неоправданное военной необходимостью, и другие преступления;

c) Преступления против человечности, а именно: убийства, истребление, порабошение, ссьлка и другие жестокости, совершенные в отношении гражданского населения до или во время войны, или преследования по политическим, расовым или религиозным мотивам с целью осуществления или в связи с любым преступлением, подлежащим юрисдикции Трибунала, независимо от того, являлись ли эти действия нарушением внутреннего права страны, где они были совершены, или нет"6.

В приговоре Международного военного трибунала над тлавными немецкими военными преступниками был подтвержден принцип индивидуальной 
уголовной ответственности за совершение агрессии, за нарушение законов и обычаев войны, а тақже были отвергнуты попытки зашиты немецких военных преступников прикрыться доктриной государственного акта и свести дело к ответственности лишь государства как такового.

Так, в притоворе Нюрнбергского трибунала по вопросу личной ответственности провозглашено:

"Давно уже было признано, что международное право налагает долг и обязанности на отдельных лиц так же, как и на государства... самая сущность Устава заключается в том, что отдельные лица имеют международные обязательства, которые превышают национальный долг повиновения, наложенный отдельным государством. Тот, кто нарушает законы ведения войны, не может оставаться безнаказанным на основании того, что он действует в соответствии с распоряжениями государства, если государство, давая свою санкцию на подобные действия, выходит за пределы своей компетениии, предоставляемой ему согласно международному праву"7.

Нюрнбергский и Токийский процессы имели огромное значение для дальнейшего развития международного права. Принципы, изложенные в Уставах и Приговорах этих трибуналов, были подтверждены резолюциями Генеральной Ассамблеи ООН 3(1) от 13 февраля 1946 г. и 95 (1) от 11 декабря 1946 г. н стали обшепризнанными принципами международного nрasa.

Дальнейшее развитие и закрепление эти принципы нашли в Конвенциях - предупреждении геноцида и наказании за него, Женевских конвенциях о зашите жертв войны от 12 августа 1949 г. и Дополнительных протоколах к ним от 8 июня 1977 г. и друтих международных договорах. Кроме того, ранее ржд запрешенных действий перечислялся в Положении о законах и обыраях сухопутной войны, прилагаемом к Конвенции о законах и обычаях сухопутной войны от 18 октября 1907 г., обычный характер которых был подчеркнут в приговоре Нюрнбергского международного военного трибунала, а Республика Беларусь присоединилась к Гаагским конвенциям 6 июня 1962 г., подтвердив обязательность для себя этих положений.

Рассмотрим более подробно положения международных договоров, касающиеся некоторых нарушений международного гуманитарного права, которые рассматриваются как серьезные нарушения. При этом необходимо отметить, что не все нарушения международного гуманитарного права влекут за собой утоловную ответственность, а только те, которые в соответствин с Женевскими конвенциями 1949 года и другими международными договорами должны пресекаться в уголовном порядке. Также в Женевских конвенциях 1949 года и других международных договорах не употребляется выражение "военные преступления", когда говорится о "серьезных нарушениях" их постановлений, но не подлежит сомнению, что при этом имеются в виду именко военные преступления и за их совершение предусматривается личная ответственность как за нарушение законов и обычаев войны. Эта терминологическая неясность объясняется стремлением подчеркнуть обязательства договариваюшихся государств пресекать запрешаемые акты и наказывать 3 а них.

Из международных договоров, направленных на защиту жертв вооруженных конфликтов и ограничение методов и средств войны, однозначно вытекает, что серьезные нарушения подлежат наказанию. Однако сами по 
себе эти договоры не определяют конкретных мер наказания и не предусматривают непосредственного учреждения трибунала для судебного преследования правонарушителей.

Так, в ст. 49 I Женевской конвенции, ст. 50 II Женевской конвенции, ст. 129 III Женевской конвенции (далее: ЖK I, ЖK II, ЖK III и т.д.) содержится норма, обшая для этих международных договоров и предусматриваюшая, что

“Каждая Высокая Договаривающаяся Сторона обязуется разыскивать лиц, обвиняемых в том, что они совершили или приказали совершить то или иное из упомянутых серьезных нарушений, и каково бы ни было их гражданство, предавать их своему суду. Она сможет также, если она этого пожелает, передать их в соответствии с положениями своего законодательства для суда другой заинтересованной Высокой Договаривающейся Стороне в том случае, если эта Договаривающаяся Сторона имеет доказательства, даюшие основания для обвинения этих лиц".

Сходные нормы содержатся и в других международных договорах. Например, в ст. 28 Гаагской конвенции о зашите культурных ценностей от 14 мая 1954 г., в ст. 14 Протокола 2 к Конвенции о запрещении применения конкретных видов обычного оружия, которые могут считаться наносящими чрезмерные повреждения или имеющими неизбирательное действие.

Как видно из приведенных положений, эти обязательства принимать необходимые меры для пресечения нарушений Конвенций являются составной частью более общего обязательства, которое содержится в ст. 1 всех Женевских конвенций 1949 года и требует от государств “соблюдать" и "заставлять соблюдать" положения этих договоров. Это обязательство носит одновременно превентивный и исправительный характер.

В этих обязательствах ясно говорится о том, что государства обязаны ввести в действне уголовное законодательство, предназначенное для наказания лиц, виновных в совершении серьезных нарушений. Они обязаны также разыскивать лиц, обвиняемых в совершении серьезных нарушений, и либо предавать их своему суду, либо передавать для суда другому государству.

Как правило, уголовное право того или иного государства применяется только к тем действиям, которые совершаются на его территории или его гражданами. Международное гуманитарное право обладает в этом смысле более широкой сферой применения. Оно обязывает государства разыскивать и наказывать всех лиц, совершивших серьезные нарушения, независимо от их гражданства и места совершения преступления. Этот принцип, именуемый универсальной юрисдикцией, явлется ключевым фактором обеспечения эффективности пресечения серьезных нарушений. Вместе с тем следует учитывать и то обстоятельство, что, несмотря на необходимость выдачи лиц, обвиняемых в совершении серьезных нарушений международного гуманитарного права, в соответствии с принципом “aut dedere aut judicare", ее не следует рассматривать как альтернативное решение, принимаемое во всех случаях. Выдача, в частности, своих граждан является исключительным событием, так как не всегда может быть сделана просьба - выдаче и не всегда у государства есть убедительные доказательства, даюшие основания для обвинения этих лиц. Таким образом, государства-учас- 
тники во всех случаях должны применять собственное уголовное захонодательство, в котором должна быть предусмотрена ответственность за серьезные нарушения международного гуманитарного права.

Исходя из анализа положений международного гуманитарного права, можно выделить перечень серьезных нарушений, которые в соответствии с обязательствами государств должны запрешаться национальным законодательством и за совершение которых должно предусматриваться наказание. Международное гуманитарное право не содержит конкретных положений о классификации серьезных нарушений, которая могла бы послужить основанием для нх типизации, в международных нормах указываются лишь те виды преступлений или правонарушений, которые по своей природе и жестокости не могут остаться безнаказанными со стороны государств. Любая дальнейшая классификация является делом самих государств с единственной обязанностью предусматривать их в своем законодательстве в той форме, ках они определяются в источниках международного гуманитарного права, или в отличной форме, но имеющей сходное содержание.

В связи с этим классифицировать серьезные нарушения международного гуманитарного права достаточно сложно, и мы дадим их перечень с указанием международных договоров, положениями которых они предусматриваются.

Впервые такне нарушения были сформулированы в Положении о законах и обычаях сухопутной войны, прилагаемом к Гаагской конвенции 1907 года, н к ним относятся:

употребление отравленного оружия или других видов оружия, способных причинять излишние страдания;

необоснованное разрушение городов и селений или их разграбление, если эти действия не вызываются военной необходимостью;

нападения каким бы то ни было способом на незашищенные города, селения, жилища или строения или их бомбардировки;

разграбление частного или общественного имущества;

вероломство;

приказ не оставлять никого в живых;

убийство или нанесение увечья неприятелю, который, сложив оружие или не имея больше средств защишаться, безусловно сдался;

незаконное использование парламентского или национального флага, военных знаков и форменной одежды неприятеля, равно как и отличительных знаков, установленных Женевской конвенцией.

События второй мировой войны и стремление человеческого сообщества предотвратить повторение катастроф, ассоциируемых с деяниями нацистов, побудили государства к формулированию норм, запрешающих подобные действия и предусматриваюших ответственность за их совершение. Дальнейшее развитие институт пресечения нарушений международного гуманитарного права получил в Женевских конвенциях 1949 года, Дополнительных протоколах к ним 1977 года и других международных договорах, регулируюших вопросы применения средств и методов ведения войны. Следует отметить, что в Женевских конвенциях и Допопнительном протоколе I перечисляются все военные преступления, упоминаемые в списках военных преступлений ранее принятых документов, в частности тех, на 
основании которых было составлено Лондонское соглашение от 8 августа 1945 г. о судебном преследовании и нақазании главных военных преступников европейских стран "оси".

Женевскими конвеншиями 1949 года определяются следуюшие серьезные нарушения:

преднамеренное убийство;

пытки и бесчеловечное обрашение;

биологические эксперименты;

преднамеренное причинение тяжелых страданий;

причинение серьезного увечья или нанесение ушерба здоровью (предусмотрены ст. 50 ЖK I, ст. 51 ЖK II, ст. 130 ЖK III, ст. 147 ЖK IV);

незаконное, произвольное и проводимое в большом масштабе разрушение и присвоение имушества, не вызываемое военной необходимостью (ст. 50 ЖK I, ст. 51 XK II, ст. 147 XK IV);

принуждение военнопленного или покровительствуемого лица служить в вооруженных силах неприятельской державы;

лишение военнопленного или покровительствуемого лица прав на беспристрастное и нормальное судопроизводство, предусмотренное Конвенциями (ст. 130 ЖK III, ст. 147 ЖK IV);

незаконное депортирование или перемешение покровительствуемого лица;

незаконный арест похровительствуемого лица;

взятие заложников (ст. 147 XK IV).

K серьезным нарушениям, определяемым в Дополнительном протоколе I 1977 'года, относятся:

нанесение ущерба, путем какого-либо преднамеренного и неоправданного действия или упушения, физическому или психическому состоянию здоровья и неприкосновенности лиц, находящихся во власти противной стороны, или интернированных, задержанных или каким-либо образом лишенных свободы в результате вооруженного конфликта; в частности, имеются в виду нанесение физических увечий, проведение медицинских или научных экспериментов, удаление тканей или органов для пересадки, а также какая бы то ни было медицинская процедура, которая не требуется по состояниюо здоровья указанного лица и не соотве гствует обшепринятым медицинским нормам, применяемым при аналогичных с медицинской точки зрения обстоятельствах к гражданам стороны, пронзводящей эту процедуру, которые не лишены свободы в какой бы то ни было форме (cT. 11);

K серьезным нарушениям относятся также действия, когда они совершаются умышленно и являются причиной смерти или телесного повреждения или ушерба здоровью (п. 3 ст. 85):

преврашение гражданского населения или отдельных гражданских лиц в объект нападения;

совершение нападения неизбирательного характера, затрагивающего гражданское население или гражданские объекты, когда известно, что такое нападение явится причиной чрезмерных потерь жизни, ранений среди гражданских лиц или причинит ущерб гражданским объектам;

совершение нападения на установки или сооружения, содержащие опасные силы, когда известно, что такое нападение явится причиной чрезмер- 
ных потерь жизни, ранений среди гражданских лиц или причинит ущерб гражданским объектам;

превращение необороняемых местностей и демилитаризованных зон в объект нападения;

совершение нападения на лицо, когда известно, что оно прекратило принимать участие в военных действиях;

вероломное использование отличительной эмблемы Красного Креста, Красного Полумесяца шли других защитных знаков.

$\mathrm{K}$ серьезным нарушениям относятся также действия, когда они совершаются умышленно и в нарушение Конвенций и. Протокола:

перемещение оккупирующей державой части ее собственного населения на оккупируемую ею территорию или депортация или перемещение всего или части населения оккупированной территории в пределах этой территории или за ее пределы;

неоправданная задержка репатриации военнопленных или гражданских лич;

применение прахтики апартенда и других негуманных и унижаюших действий, оскорбляющих достоннство личности, основанных на расовой дискриминацин;

превращение ясно опознаваемых исторических памятников, произведений искусства или мест отправления культа, которые являются культурным или духовным наследием народов и которым предоставляется особая защита, в объект нападения, в результате чего им наносятся большие разрушения, когда такие объекты не находятся в непосредственной близости от военных объектов и не используются противной стороной для поддержки военных усилий;

лишение лица, пользующегося зашитой Конвенций и Протокола I, права на беспристрастное и нормальное судопроизводство.

Кроме того, в положениях Конвенцин о зашите культурных ценностей в случае вооруженного конфликта от 14 мая 1954 г., Конвенции о запрешении военного или любого иного враждебного использования средств воздействия на природную среду от 10 декабря 1976 г., Конвенции о запрешекии или ограничении конкретных видов обычного оружия, которые могут считаться наносящими чрезмерные повреждения или имеюшими неизбирательное действие от 10 октября 1980 г., Конвенции о запрешении разработки, пронзводства и накопления запасов бактериологического (биологического) и токсинного оружия и об их уничтожении от 10 апреля 1972 г., Конвенгии - запрешении разработки, производства, накопления и применения химического оружия и о его уничтожении от 13 января 1993 г. также определяется ряд серьезных нарушений международного гуманитарного права, связанных с применением недозволенных средств и методов ведения войны.

Как отмечалось выше, в соответствии с п. 1 ст. 49, 50, 129, 146 всех четырех Женевских конвенций 1949 года государства-участники должны ввести в свое законодательство положения, устанавливающие эффективные уголовные наказания для лиц, совершивших или приказавших совершить те или иные серьезные нарушения Женевских конвенций. Вышеназванные серьезные нарушения принято именовать военными преступлениями. Действуюшее утоловное законодательство Республики Беларусь не содержит 
данного понятия и устанавливает утоловную ответственность только за "воинские преступления". При этом воннскими преступлениями признаются предусмотренные Уголовным кодексом преступлення против установленного порядха несения воинской службы, совершенные военнослужацими Вооруженных Сил Республики Беларусь, а также военнообязанными во время прохождения ими сборов.

В главу 16 "Воннские преступления" Уголовного кодекса включены некоторые составы преступлений, которые по сути представляют собой серьезные нарушения международного гуманитарного права.

Статья 255 УК Республики Беларусь предусматривает ответственность за похищение на поле боя вещей, находящихся при убитых и раненых (мародерство).

Установлена уголовная наказуемость и за совершение разбоя, противозаконное уничтожение имушества, насилие, а равно противозаконное отобрание имущества под предлогом военной необходимости, совершаемые по отнопенио к населению в районе военных действий (ст. 256); за дурное обращение с военнопленными, имевшее место неоднократно или сопряженное с особой жестокостью, или направленное против раненых и больных, а равно за небрежное исполнение обязанностей в отношении больных и раненых лицами, на которых возложены лечение и попечение о них, при отсутствии признаков более тяжкого преступления (ст. 257).

Дурное обращение с военнопленными, содержашее признаки более тяжких преступлений (убийство, тяжкие телесные повреждения, изнасилования и т.д.), не охватывается ст. 257 УК РБ и подлежит квалифнкации по совокупности по другим статьям Кодекса.

Тахже в ст. 258 предусматривается нахазание за ношение в районе военных действий знаков Красного Креста или Красного Полумесяца лицами, не имеюшими на то права, а равно злоупотребление в военное время флагами нли знаками Красного Креста или Красного Полумесяца или окраской, присвоенной транспортным средствам санитарной эвакуации.

Как уже отмечалось, действующее утоловное законодательство Беларуси не предусматривает ответственгости за совершение военных преступлений и определяет ограниченный перечень составов воинских преступлений, которые по своему содержанию содержат утоловную ответственность за совершение серьезных нарушений международного гуманитарного права. Анализ захонодательства Республики Беларусь на предмет соответствия нормам международных договоров, определяющих серьезиые нарушения мехдународного гуманитарного права, позволяет сделать вывод о неполной реализации принятых обязательств.

В настоящее время Палатой представителей Национального-собрания Республики Беларусь принят в первом чтении проект Уголовного кодекса Республики Беларусь, который предусматривает достаточно широкий перечень новелл, призванных обеспечить реализацию международных обязательств в части введения в действие законодательства, необходимого для пресечения тех или иных нарушений международного гуманитарного права.

С законодательной точки зрения включение во внутригосударственное право той или иной нормы, необходимой для пресечения нарушений международного гуманитарного права, возможно при решении двух проблем: 
речь идет об определении состава преступления (процедуре признания на национальном уровне общественно опасными нарушеннй международного гуманитарного права) и о том, в какой форме и куда следует его включать в национальное законодательство.

Сушествует несколько способов, с помошью которых законодатель может включать в национальное уголовное законодательство меры наказания за серьезные нарушения международного гуманитарного права. Во-первых, это применение существуюшего общего национального утоловного законодательства и военно-утоловного законодательства (система двойного определения состава преступления). Во-вторых, путем обшего определения состава преступления с ссьлкой на соответствующие положения международного гуманитарного права. В-третьих, путем частного определения состава преступления, когда воспроизводятся текст положений международных договоров либо приводятся отдельные определения действий, которые квалифицируются как преступные. И наконец, в-четвертых, сочетание этих способов. Анализ положекий проекта Уголовного кодекса показывает, что при его разработке было использовано сочетание вышеуказанныг способов, за исключением двойного определения состава преступления.

Так, в проекте Уголовного кодекса содержится глава 19 "Военные преступления и другие нарушения законов и обычаев войны”. Глава состоит из семи статей, предусматриваюших уголовную нахазуемость $3 а$ совершение обшественно опасных деяний, связанных с нарушением законов и обычаев войны. Особенностью является то, что в проекте составы преступлений, содержащиеся в указанных статьях, составляют новый вид уголовно наказуемых деяний - военные преступления, субъектом которых могут быть как военнослужашие, так гражданские лица. Это позволит осуществлять правосудие как военным судам, так и судам общей юрисдикции.

Рассмотрим подробнее, составы каких преступлений предусматриваются в этой главе проекта Уголовного кодекса.

Статьями 131 и 132 устанавливается уголовная ответственность за вербовку, обучение, финансирование, иное материальное обеспечение и использование наемников для военных действий против другого государства или противодействия законному осуществлению права народов на самоопределение, признанного международным правом, а также уголовная наказуемость наемничества.

Статья 133 определяет уголовно наказуемым пронзводство, приобретение, хранение, перевозку, пересылку либо сбыт запрешенных международными договорами Республики Беларусь средств массового уничтожения или иных запрешенных средств ведения войны либо составляющих $\mathrm{K}$ ним, равно проведение исследований, направленных на изготовление или применение таких средств. Статъя 134 соответственно запрешает применение в вооруженном конфликте средств и методов, запрешенных международными договорами Республики Беларусь, особо выделяя наказуемость применения оружия массового поражения, запрещенного таким договором.

Статьи 135 и 136 содержат составы преступлений, связанные с нарушениями законов и обычаев войны, а также норм международного гуманитарного права. Так, ст. 135 предусматривает уголовную наказуемость за совершение умышленного убийства лиц, сдавших оружие либо не имеющих 
средств защиты, раненых, больных, потерпевших кораблекрушение, медицинского и духовного персонала, военнопленных, гражданского населения на оккупированной территории или в райо̀н боевых действий, иных лиц, пользугошихся во время военных действий международной зашитой, за причинение тяхкого вреда здоровью лицам, названным выше, истязание, проведение над ними, даже с их согласия, медицинских, биологических и других экспериментов, нспользование этих лиц шля прикрытия своих войск или объектов от военных действий, захват и удержание таких лиц в качестве заложников, угон гражданского населения для принудительных работ. Также в соответствии со ст. 135 противоправно принуждение лиц, пользуюшихся покровительством Женевских конвенций 1949 года, к службе в вооруженных силах противника, переселению, лишение их права на незавнснмый н беспристрастный суд, ограничение права этих лиц на защиту в уголовном судопроизводстве.

Статья 136 определяет перечень нарушений международного гуманитарного права, за совершение которых проект Угаловного кодекса предусматривает уголовную ответственность. $\mathrm{K}$ таким нарушениям отнесены:

применение оружия, средств и методов ведения войны, которые могут считаться наносящими чрезмерные повреждения или имеющими неизбирательное действие;

умышленное причинение обширного, долговременного и серьезного ущерба природной среде;

нападения на строения, оборудование, транспортные формирования, транспортные средства, а также персонал, обладағщие с защитной целью отличительными знаками Красного Креста и Красного Полумесяца;

использование голода среди гражданского населения в качестве ведения военных действий;

вербовка детей, не достигших пятнадцатилетнего возраста, в вооруженные силы или разрешение им принимать участие в военных действиях;

отдание приказа не оставлять никого в живых;

произвольное и производимое в большом масштабе разрушение или присвоение имушества, не вызываемое военной необходнмостью;

преврашение необороняемых местностей и демилитаризованных зон в объект нападения;

преврашение в объект нападения ясно опознаваемых исторических памятников, произведений искусства или мест отправления культа, находящихся под особой защитой, при отсутствии военной необходимости;

нарушение соглашений о перемирии, о приостановлении военных действий шли местных соглашений, заключенных с целью вывоза, обмена или перевозки раненых и умерших, оставленных на поле сражения.

И наконец, ст. 137 проекта Уголовного кодекса предусматривает утоловную ответственность за умышленное использование вопреки международным договорам во время военных действий знаков Красного Креста, Красного Полумесяца, Красного Льва или Красного Солнца, а равно охранных знахов для культурных ценностей либо иных знаков, охраняемых международным правом, а также пользование государственным флагом или государственными отличиями неприятеля, нейтрального государства, флагом или знаком международной организации. 
Кроме того, наряду с противоправными деяниями, предусматриваемыми Разделом IV, в проекте Уголовного кодекса содержится ряд новелл, позволяющих обеспечить реализацию положений ст. 88 Дополнительного протокола I о сотрудничестве в вопросах уголовного преследования лиц, совершивших военные преступления, равно как и в вопросах выдачи военных преступников. Так, в соответствии с частью третьей ст. 6 проекта Уголовного кодекса уголовное законодательство Республики Беларусь применяется независимо от уголовного права места совершения деяния в отношении следующих преступлений: геноцид (ст. 127), преступления против безопасности человечества (ст. 128), применение запрещенных средств и методов ведения войны (ст. 134), нарушения законов и обычаев войны (ст. 135), преступные нарушения норм международного гуманитарного права во время вооруженных конфликтов (ст. 136), а равно в отношении иного преступления, совершенного вне пределов Республики Беларусь, подлежашего преследованию на основании обязательного для Республики Беларусь международного договора. Статьей 7 определяется возможность выдачи лиц, совершивших преступления вне пределов Республики Беларусь и подлежащих преследованию на основании обязательного для Республики Беларусь международного договора.

Согласно ст. 84, освобождение от уголовной ответственности или наказания в связи с нстечением сроков давности не применяется при совершении преступлений против мира, безопасности человечества и военных преступлений.

Безусловно, введение в проект Уголовного кодекса Раздела IV “Преступления против мира, безопасности человечества и военные преступления" является важным шагом, направленным на реализацию гуманитарных обязательств Беларуси. Вместе с тем необходимо отметить ряд недостатков, которые возможно было бы учесть при доработке в Парламенте проекта указанного Кодекса.

Ках уже отмечалось, в соответствии с положениями Женевских конвенций 1949 года и Дополнительного протокола I государства обязаны преследовать в уголовном порядке лиц, совершивших серьезные нарушения международного гуманитарного права в период вооруженных конфликтов. В связи с этим представляется, чтобы в уголовном законодательстве Республики Беларусь была в полном объеме предусмотрена уголовная нахазуемость за совершение общественно опасных деяний, определяемых ках серьезные нарушения.

Вместе с тем глава 19 проекта Уголовного кодекса не предусматривает ответственности за совершение ряда военных преступлений, определяемых в четырех Женевских конвенциях и Дополнительном протоколе I, в частности за совершение нападения на гражданское население или на отдельных гражданских лиц; совершение нападения неизбирательного характера, затрагиваюеего гражданское население или гражданские объекты, когда известно, что тахое нападение явится причиной чрезмерных потерь жизни, ранений среди гражданских лиц или причинит ушерб гражданским объектам; совершение нападения на установки или сооружения, содержащие опасные силы, когда известно, что такое нападение явится причиной чрезмерных потерь жизни, ранений среди гражданских лиц или причинит ушерб 
гражданским объектам, которые были бы чрезмерными по отношению к конкретному и непосредственному военному преимуществу, которое предполагается таким образом получить; совершение нападения на лицо, когда известно, что оно прекратило принимать непосредственное участие в военных действиях; перемещение оккупирующей державой части ее собственного гражданского населения на оккупируемую ею территорию; неоправданная задержка репатриации военнопленных и гражданских лиц.

Кроме того, проект Уголовного кодекса не содержит обшего положения, вытекающего из п. 2 ст. 86 Дополнительного протокола I и обеспечивающего ответственность начальника за совершение подчиненным лицом серьезных нарушений международного гуманитарного права в той мере, в какой этот начальник знал или должен был знать о нарушении и не принял необходимых мер для предупреждения или пресечения.

Представляется не совсем удачным формулирование в виде обшей отсьлки диспозиции части первой ст. 134 проекта Уголовного кодекса. На практике данная норма будет вызывать много проблем в силу того, что не содержит указания ни о конкретных, запрешенных международным договором, средствах и методах ведения войны, ни о самих международных соглашениях, предусматриваюших подобные положения. Кроме того, ряд международных договоров наряду с запретом применения определенных средств ведения вооруженной борьбы в период вооруженных конфликтов содержат нормы, запрешакщие производство, накопление и распространение запрещенных средств ведения войны как в военное, так и в мирное время. Там же предусматриваются положения о контрольных механизмах реализации договоров. Примером таких договоров могут служить конвенции о запрешении разработки, прокзводства и накопления запасов бактериологического (биологического) и токсинного оружия и об их уничтожении, о запрешении разработки, производства, накопления и применения химического оружия и др.

Статьей 137 проекта предусматривается уголовная наказуемость умышленного использования во время военных действий знаков Красного Креста, Красного Полумесяца, Красного Льва и Красного Солнца. Думается, что ограничение ответственности за неправомерное использование защитных эмблем только периодом военных действий является не вполне обоснованным и отвечающим положениям международного гуманитарного права. Подход об уголовной наказуемости незаконного использования эмблем Красного Креста и Красного Полумесяца в мирное время, закрепленный в ст. 198 действуюшего уголовного закона, более оправдан и позволяет обеспечивать уважение и защиту данных знаков от различного рода злоупотреблений.

Работа над проектом Уголовного кодекса, и в частности над Разделом VI "Преступления против мира, безопасности человечества и военные преступления", является принципиально новым, важным этапом формирования утоловного захонодательства, не только направленным на реализацию гуманитарных обязательств Беларуси, но и имеюшим большое предупредительное значение, призванным обеспечить необходимые гарантии для гражданского населения и лиц, не принимағощх или прекративших принимать участие в боевых действия. Законодательное закрепление наказуе- 
мости всех серьезньх нарушений Женевских конвенций 1949 года и Дополнительных протохолов к ним 1977 года позволит Республике Беларусь в полной мере и эффективно выполнить свои международные обязательства в области пресечения военных преступленнй.

1 Jose Louis Fernandez Flores. Lempechement des violations du droit de guerre/l Revue international de la Croix-Rouge. -1991. - Mai-Juin. - № 789. - P. 264.

${ }^{2}$ Сборних действующнх договоров, соглашений и конвенций. - Вып. XI. - M., 1955. - C. 48.

${ }^{3}$ Арцибасов И.Н. Международное право. Учебное пособие. - М., 1989. - С.333.

4 Тегеран-Ялта-Потсдам. Сборних документов. - М., 1967. - С. 143.

5 Там же. - C. 345.

- Нюорнбергский процесс над главными немецхими военными преступниками. Сборник материалов (В семи томах)/Под общей редакцией Р.А. Руденко. - Т. 7. - М., 1957-1961. - C. 122.

1 Taм жe. - C. 366.

- Yves Sandoz. Penaal Aspects of International Humanitarian Law // International Criminal Law. - Vol. I. Crimes. Cherif Bassiouni. -N.Y., 1986. - P. 225.

г. Минск

Статья поступила в редакчию в декабре 19972. 